\title{
Effect of asymptomatic bacteriuria on pregnancy outcome: a review
}

\author{
Neelima Nalam, Ushadevi Gopalan*
}

Department of Obstetrics and Gynaecology, Shri Sathya Sai Medical College and Research Institute, Ammapettai, Tamil Nadu, India

Received: 28 January 2021

Accepted: 04 March 2021

\section{*Correspondence:}

Dr. Ushadevi Gopalan,

E-mail: ushag7@hotmail.com

Copyright: (C) the author(s), publisher and licensee Medip Academy. This is an open-access article distributed under the terms of the Creative Commons Attribution Non-Commercial License, which permits unrestricted non-commercial use, distribution, and reproduction in any medium, provided the original work is properly cited.

\section{ABSTRACT}

Asymptomatic bacteriuria is more common in pregnancy and if left untreated it may progress to upper urinary tract infection. Early detection and treatment of asymptomatic bacteriuria prevents further progression of the infection and thereby preventing undesirable complications to the mother and fetus. It is advisable to do Urine culture and sensitivity in all antenatal women irrespective of the gestational age and symptoms.

Keywords: Asymptomatic bacteriuria, Pregnancy outcome, Urinary tract infections

\section{INTRODUCTION}

During pregnancy, women have more chances to acquire asymptomatic bacteriuria due to the physiological and morphological changes occurring in them and also due to the immune-compromised status of the pregnant women. ${ }^{1}$ ASB is more common in women due to short urethra and urethra is more proximal to the anal canal. Urinary tract infections can be symptomatic or asymptomatic. ${ }^{2}$

\section{Study design}

A narrative review of published literature.

\section{ANATOMY AND FUNCTIONS OF THE URINARY TRACT}

Urinary tract is made up of renal papillae, renal pelvis, ureters, urinary bladder and urethra from proximal to distal. ${ }^{3}$ Upper urinary tract includes kidney and ureters. Lower urinary tract includes urinary bladder and urethra. Kidney plays a crucial role in taking off the unwanted waste (water soluble) from the blood and also helps in reabsorption of key elements like water, amino acids and glucose. ${ }^{4}$ Toxic and metabolic products which are produced in the kidney are excreted by urinary tract. Collection, transportation, storage and expulsion of urine is the main function of the urinary tract. ${ }^{5}$

Urine is formed in the kidney which is transported to the urinary bladder through a tubular structure called as ureters. This urine is accumulated in the urinary bladder (a muscular organ) before its excretion through the urethra. ${ }^{4}$ In general whole of the urinary tract is sterile except the distal urethra. Invasion of microorganisms beyond this urethra leads to Asymptomatic bacteriuria. ${ }^{6}$

\section{CHARACTERISTICS OF URINE}

Urine is straw coloured odourless fluid with $\mathrm{pH}$ of 4.5-8, and specific gravity of 1.003-1.032. Osmolarity of urine varies from 40-1350. Rate of excretion of urine is 1-2 L/ day 3. In normal urine, cells like RBC's, WBC's and pus cells are not excreted. Usually protein is not excreted in urine. Proteinuria indicates damage to the glomeruli as a result of infection. ${ }^{7}$

Characteristics of urine such as high osmolarity, acidic or low $\mathrm{pH}$, and high concentration of urea has a bacteriostatic 
effect. Alteration in these characteristics of urine provides good medium for the bacterial growth. ${ }^{8}$

\section{TYPES OF URINARY TRACT INFECTION}

Can be classified into asymptomatic or symptomatic.

"Asymptomatic bacteriuria is defined as growth of same species of more than $10^{5}$ colonies/ $\mathrm{ml}$ of urine in a clean catch midstream urine sample in women without any symptoms." 9

Symptomatic urinary tract infections are further divided:

Upper urinary tract infection: pyelonephritis or infection involving kidney.

Lower urinary tract infection: cystitis or infection of urinary bladder

symptoms of urinary tract include frequent urination, pain during micturition, blood in urine and urgency. Systemic symptoms such as fever with chills, flank pain and low back ache are usually seen in upper urinary tract infection. ${ }^{6}$

\section{RISK FACTORS FOR URINARY TRACT INFECTION}

Women are at increased risk of developing urinary tract infection as compared to men because in women urethra is placed close to the anus.

\section{Low socioeconomic status}

Poor genital hygiene and lack of education

Sexual activity at a very young age

Elderly gravida

Few medical and immunocompromised conditions such as pregnancy, diabetes mellitus, acquired immuno deficiency syndrome/ HIV, renal stones or anomalies of urinary tract, nosocomial infections

Prolonged hospital stay or catheterization. ${ }^{10}$

\section{PHYSIOLOGICAL CHANGES IN PREGNANCY AND ASB}

Progesterone, the pregnancy hormone reduces the peristalsis and muscle tone, there will be dilatation of the renal pelvis and ureter, there by reduced flow of urine, urinary stasis and a state of hydronephrosis. As the gestational age advance, enlarging uterus causes obstruction to the flow of urine and urinary stasis. Tone of the bladder is decreased, and bladder capacity is increased. This when associated with incomplete emptying may lead to vesicoureteric reflex further leading to migration of bacteria. These changes which occur in pregnancy provides an environment for the growth of bacteria. ${ }^{6}$

During pregnancy $\mathrm{pH}$ of urine is raised which is suitable for the growth of bacteria. Glycosuria in pregnancy is common as the glomerular filtrate is raised in pregnancy and glucose from the glomerular filtrate cannot be reabsorbed completely by the renal tubules. This excessive glucose in urine is a good media for the growth of bacteria in urine. ${ }^{11}$

\section{ASB IN PREGNANCY}

In many studies prevalence of Asymptomatic bacteriuria in pregnancy ranges from $2-11 \% .{ }^{9}$ Whereas in India and other developing countries, prevalence is more especially in people belonging to lower socioeconomic status due to inability to maintain good genital hygiene and not practising sanitizing measures, lack of knowledge and non availability of medical resources in remote locations. These group of people are unaware of the consequences and complications associated with untreated bacteriuria and effects on mother and fetus. ${ }^{12}$ Diabetes mellitus and Sickle cell disease increases the risk of asymptomatic bacteriuria. $^{6}$

\section{ASB AND PREGNANCY OUTCOME}

If Asymptomatic bacteriuria is left untreated in pregnancy it may progress to pyelonephritis. Untreated bacteriuria may cause complications in mother such as preterm labour, anaemia, hypertensive disorders, postpartum endometritis and chorio amnionitis. Complications in neonate such as prematurity, low birth weight, IUGR, perinatal mortality and morbidity. ${ }^{1}$

Various explanations for the association of pyelonephritis and preterm labour include:

Myometrial activity is increased due to pyrogens

Gram negative bacteria produces endotoxins which has an oxytocic effect on cells of myometrium.

Endotoxins can cross the placenta and affect fetus by causing preterm labour

Bacterial enzymes such as collagenase and proteases can cause membranes rupture and initiates labour.

Prostaglandin synthesis by decidua is stimulated by bacterial products like endotoxins and phospholipase which leads to onset of labour.

Prostaglandins are secreted as the bacterial products activate cells like macrophages, monocytes which in turn leads to labour.

Prostaglandin secretion is triggered by cytokines (Interleukin-1 and 6, platelet activating factor, tumour 
necrosis factor) which in turn are released by activation of cells such as macrophages and monocytes. ${ }^{6}$

\section{MICROORGANISMS CAUSING ASB}

Of all the microorganisms Escherichia coli, the gramnegative bacteria is the most common bacteria causing urinary tract infection in pregnancy. Other organisms causing Asymptomatic bacteriuria are Klebsiella pneumoniae, Proteus mirabilis, Enterobacter species, Pseudomonas and gram-positive bacteria like Streptococcus, Staphylococcus and Enterococcus. ${ }^{13}$

Urine culture is the gold standard test for the diagnosis of Asymptomatic bacteriuria in pregnancy. Other screening tests such as nitrate test, leucocyte esterase test can be used to screen pregnant women for Asymptomatic bacteriuria. ${ }^{14}$

\section{SELECTION OF STUDIES}

A study conducted by Kerure et al included 300 pregnant women who were examined for asymptomatic bacteriuria in pregnancy. $11 \%$ of them were found to have significant bacteriuria. They concluded urine culture to be the most sensitive test for detection of Asymptomatic bacteriuria and also said that it was important to screen all pregnant women for Asymptomatic bacteriuria at their 1st antenatal visit. $^{2}$

Jain et al conducted a prospective cohort study on pregnant women without any symptoms of urinary tract infection and found prevalence of Asymptomatic bacteriuria to be $16.9 \%$. They found that in group of women where early detection and treatment of asymptomatic bacteriuria was done there was significant reduction in development of complications to the mother and baby. They also found that detection of asymptomatic bacteriuria late in pregnancy showed increased occurrence of complications like preterm labour, preterm premature rupture of membranes, pre - eclamptic toxaemia, Intrauterine growth retardation and low birth weight even after treatment of bacteriuria. They concluded that screening of asymptomatic bacteriuria should be a part of routine antenatal care and should treat bacteriuria positive cases for the safe health of mother and neonate. ${ }^{9}$

Radha et al conducted a study on 400 pregnant women with gestational age less than 28 weeks and showed $8.25 \%$ prevalence of Asymptomatic bacteriuria. They concluded that maternal morbidity was as high as $24.2 \%$ and fetal morbidity was $24 \%$ in women with asymptomatic bacteriuria as compared to those who were not having significant bacteriuria. They recommended routine screening of all pregnant women for Asymptomatic bacteriuria in early pregnancy. ${ }^{15}$

Mukherjee et al conducted a cross sectional study on 250 antenatal women of which prevalence of Asymptomatic bacteriuria was $8.4 \%$. They found Gram staining of the uncentrifuged urine to be useful test. The sensitivity of leukocyte esterase test and nitrite test alone was $71.42 \%$ but combined tests with either test positive showed sensitivity of $90.47 \%$ and negative predictive value of $99.09 \%$ which may be an alternative to screen all pregnant women with urine culture. ${ }^{16}$

Acharya et al conducted a study on 350 pregnant women, prevalence of asymptomatic bacteriuria was found to be $9.14 \%$. They suggested to screen for asymptomatic bacteriuria in all trimesters of pregnancy using urine culture and also to treat the urine culture positive cases with susceptible antibiotics to prevent maternal and fetal complications. $^{17}$

\section{CONCLUSION}

Asymptomatic bacteriuria is more common in females and in pregnancy. If left untreated it will progress into symptomatic urinary tract infections and pyelonephritis. Pyelonephritis has an adverse maternal and fetal outcome. Early detection and treatment of Asymptomatic bacteriuria can prevent the adverse outcomes which can be achieved by routine screening for Asymptomatic bacteriuria in all antenatal patients as early as possible. Urine culture is always considered to be the gold standard diagnostic test for detection of bacteriuria. Appropriate antibiotic therapy according to the sensitivity pattern can prevent development of resistance to antibiotics.

Funding: No funding sources

Conflict of interest: None declared

Ethical approval: Not required

\section{REFERENCES}

1. Gehani M, Kapur S, Bhardwaj P, Nag V, Balasubramaniam SM, Kammili N. Unmet need of antenatal screening for asymptomatic bacteriuria: A risk factor for adverse outcomes of pregnancy. Indian J Community Med. 2019;44(3):193-8.

2. Kerure RD, Umashanker. Prevalence of Asymptomatic Bacteriuria among Pregnant women in a teritiary care hospital. Int J Sci Res Publ. 2013;3(11):1-4.

3. Abdullahi HI, Thairu Y. Asymptomatic Bacteriuria among Pregnant Women Attending Antenatal: Evaluation of Screening Test. IOSR J Of Pharmacy. 2015;5(8):41-47.

4. Vasudevan R. Urinary tract infection: an overview of the infection and the associated risk factors. J Microbiol Exp. 2014;1(2):42-54.

5. Hickling DR, Sun TT, Wu XR. Anatomy and Physiology of the Urinary Tract: Relation to Host Defense and Microbial Infection. Urinary tract infections: Molecular pathogenesis and clinical management. 2017;15:1-25.

6. Kalita D, Deka S. Asymptomatic bacteriuria in pregnancy. The New Indian Journal of OBGYN. 2015;2(1):8-19. 
7. Ghamrawi R, Kattah AG, Garovic VD. Isolated Proteinuria of Pregnancy: A Call for Action. Kidney Int Rep. 2019;4:766- 8.

8. Jennifer P, Cyril R, Piyumi P, Nimesha G, Renuka J. Aymptomatic Bacteriuria in Pregnancy: Prevalence, Risk factors and Causative Organisms. Sri Lankan J Inf Dis. 2012;1(2):42-6.

9. Jain V, Das V, Agarwal A, Pandey A. Asymptomatic bacteriuria and obstetric outcome following treatment in early versus late pregnancy in north Indian women. Indian J Med Res. 2013;137:753-8.

10. Behzadi P, Behzadi E, Yazdanbod H, Aghapour R, Cheshmeh A, Omran DS. A survey on urinary tract infections associated with the three most common uropathogenic bacteria. Maedica. 2010;5(2):111-5.

11. Banda JM, Cletus D, Sheyin Z, Junaid SA, John B, Mohammed SSD. Prevalence of Asymptomatic Bacteriuria among Pregnant Women Attending Antenatal Clinic at Plateau State Specialist Hospital, Jos, Nigeria. Arch Microbiol Immunology. 2020;4(3):121-30.

12. Jayachandran AL, Gnanasambandam U, Balan K, Sangeetha AV, Vijayalakshmi TS. Asymptomatic bacteriuria among antenatal women attending a tertiary care hospital in Kanchipuram: evaluation of screening tests and antibiotic susceptibility pattern. Int J Res Med Sci. 2016;4(2):540-4.
13. Gopalan U, Rajendiran S, Karnaboopathy. Screening for Asymptomatic bacteriuria in pregnant women. Indian J Obstet Gynaecol. 2017;5(3):367-71.

14. Baksh ME, Tadi S, Darabi R. Asymptomatic bacteriuria in pregnant women attending Boo- Ali Hospital Tehran Iran: Urine analysis vs. Urine culture. Electronic physician. 2017;9(11):5760-3.

15. Radha S, Nambisan B, Prabhakaran NK, Jamal S. Prevalence and outcome of asymptomatic bacteriuria in early pregnancy. Int $\mathbf{J}$ Reprod Contracept Obstet Gynecol. 2017;6(1):223-7.

16. Mukherjee K, Golia S, Vasudha CL, Babita, Bhattacharjee D, Chakroborti G. A study on asymptomatic bacteriuria in pregnancy: prevalence, etiology and comparision of screening methods. Int $\mathbf{J}$ Res Med Sci. 2014;2(3):1085-91.

17. Acharya R. Asymptomatic urinary tract infections among pregnant women attending antenatal clinic at tertiary care hospital. J Evid Based Med Healthc. 2019;6(14):1122-4.

Cite this article as: Nalam N, Gopalan U. Effect of asymptomatic bacteriuria on pregnancy outcome: a review. Int J Reprod Contracept Obstet Gynecol 2021;10:1753-6. 